\title{
Comparison between the Effectiveness of Rotary and Manual Instrumentation in Primary Teeth: A Systematic Review
}

\author{
Veerale Panchal ${ }^{1}$, Ganesh Jeevanandan², Subramanian MG Erulappan ${ }^{3}$
}

\begin{abstract}
Aim:To develop a scientifically current and evidence based protocol on the efficacy of rotary and hand root canal instrumentation in primary teeth. Materials and methods: Previous randomized control trials were used for the current review. Hand search and online search engines of PUBMED and Google Scholar were used to search English language articles with human subjects published up to December 2016.

Results: After screening of the abstracts and articles, based on the inclusion and exclusion criteria a total of 13 articles were included in the systematic review.

Conclusion: Rotary instrumentation shows equivalent cleaning efficiency than hand files depending on the system of instrumentation and techniques used. However, use of rotary in primary teeth leads to improved shaping of canals providing better quality of treatment in less time. Keywords: Cleaning efficiency, Debris, K-files, Rotary files, Smear layer. International Journal of Clinical Pediatric Dentistry (2019): 10.5005/jp-journals-10005-1637
\end{abstract}

\section{INTRODUCTION}

Dentistry has faced numerous improvements in earlier years. In the field of pulp therapy, there has been improvement not only with the materials used but also with the techniques used for instrumentation. Improvement in technique results in better quality of work with reduction in time. The introduction of rotary instrumentation started with NiTi systems introduced as early as 1960 by Buelher; ${ }^{1}$ which at that time became popular for orthodontic wires and dental burs. K-type root canal files were made and tested extensively by Serene et al. ${ }^{2}$ and the first NiTi rotary appeared on the market around 1993. These early rotary files introduced did not have cutting edges but rather had broad radial lands. Those files retained the $16 \mathrm{~mm}$ long cutting blade but had a greater taper than typical 0.02 for $\mathrm{K}$ files. ${ }^{3}$ A newer form of the rotary system was introduced as the modification of the traditional rotary system.

Barr et al. was the first to use rotary NiTi files for primary root canal preparation. ${ }^{4}$ They reported that use of NiTi files for root canal preparation in primary teeth was cost-effective, faster, and resulted in uniform and predictable fillings. Investigators have evaluated various root canal systems and compared the efficacy of instrumentation between the hand and rotary files. A comparative evaluation of time taken for the pulp therapy procedure has been published. Each study has its own unique method of evaluation of the effectiveness of the root canal system, thus giving a literature of various methods available. ${ }^{5-7}$

The aim of this study is to systematically and qualitatively review and evaluate the effectiveness of instrumentation between hand and rotary files in primary teeth.

\section{Materials and Methods}

This systematic review was approved by the ethics approval committee of Saveetha University with reference number (STP/ SDMDS16PED3).
${ }^{1-3}$ Department of Pedodontics and Preventive Dentistry, Saveetha Dental College, Chennai, Tamil Nadu, India

Corresponding Author: Veerale Panchal, Department of Pedodontics and Preventive Dentistry, Saveetha Dental College, Chennai, Tamil Nadu, India, Phone: +91 9967518954, e-mail: veerale60193@gmail.com How to cite this article: Panchal V, Jeevanandan G, et al. Comparison between the Effectiveness of Rotary and Manual Instrumentation in Primary Teeth: A Systematic Review. Int J Clin Pediatr Dent 2019;12(4):340-346.

Source of support: Nil

Conflict of interest: None

\section{Search Strategy and Study Selection}

The research question formulated was according to PICO (Table 1) which says "In primary teeth pulpectomy procedures $(\mathrm{P})$, there is a difference using rotary instrumentation (I) compared to hand filing instrumentation $(C)$ in terms of cleaning efficiency of the canals $(O)^{\prime \prime}$.

A comprehensive literature search was conducted to identify the available literature up to December 2016 using the PubMed/ MEDLINE database. The reference list of reviews and selected studies was also hand searched to retrieve all the papers which might be omitted during the database search. The search strategy was performed as follows:

Rotary or Mechanical instrumentation or ProTaper or Mtwo or $\mathrm{k} 3$ or Heroshapers and hand instrumentation or $\mathrm{K}$ files and pulpectomy and pulp therapy.

Table 1: Research question in PICO format

\begin{tabular}{ll}
\hline Participants & Primary teeth \\
\hline Intervention & Rotary instrumentation \\
Comparison & Hand instrumentation \\
Outcome & Cleaning efficiency \\
\hline
\end{tabular}

() The Author(s). 2019 Open Access This article is distributed under the terms of the Creative Commons Attribution 4.0 International License (https://creativecommons. org/licenses/by-nc/4.0/), which permits unrestricted use, distribution, and non-commercial reproduction in any medium, provided you give appropriate credit to the original author(s) and the source, provide a link to the Creative Commons license, and indicate if changes were made. The Creative Commons Public Domain Dedication waiver (http://creativecommons.org/publicdomain/zero/1.0/) applies to the data made available in this article, unless otherwise stated. 
Initially the title and abstracts of the relevant studies were identified and assessed by two reviewers independently. The inclusion and exclusion criteria are as follows:

\section{Inclusion Criteria}

- All the studies comparing hand and rotary files.

- Studies on primary teeth published in PubMed indexed journals.

- Studies published in English language from January 2004 to December 2016.

\section{Exclusion Criteria}

- Studies which compare permanent dentition.

- Studies which do not mention the effectiveness of cleaning efficacy and time taken.

\section{Data Collection}

The required information of the eligible studies was collected by one reviewer. However, the other reviewer cross checked all the retrieved information. For each study the following data was systematically recorded: publication details, sample size, number of samples according to instrumentation technique used, methodology used for comparison and comparative analysis.

\section{Assessment of Risk of Bias}

The assessment of the risk of bias-based on in vitro studies was conducted based on an analysis previously recorded by Sivakumar et al. ${ }^{8}$ This analysis was modified for the present systematic review.

The checklist includes the scoring based on tooth selection, number of sites assessed, study setting, number of observers, test reliability report, validation method, validation criteria and validation reliability (Table 2 ). The total score calculated ranged from $0-20$ which was rescaled from $0-100^{9}$ as percentage by multiplying assigned points by 5 . All the studies having the score above 55 were regarded as very high quality and have low risk of bias, score below 55 was considered having average risk of bias, whereas those having scores below 45 as considered as having high risk of bias. ${ }^{9}$

\section{Results}

\section{Study Selection}

A systematic search (Flowchart 1) identified a total of 21 studies included from the PubMed search. A total of 17 studies were selected based on the screening of abstracts and titles. Finally 13 studies were included in the review, based on the inclusion and exclusion criteria. The major factor for the exclusion of the study
Table 2: Scoring criteria for assessing the risk of bias of included studies

\begin{tabular}{|c|c|c|}
\hline $\begin{array}{l}\text { Elements of internal } \\
\text { validity }\end{array}$ & Points & Criteria \\
\hline \multirow[t]{4}{*}{ Tooth selection } & 3 & Both posterior and anterior teeth \\
\hline & 2 & Only anterior or only posterior teeth \\
\hline & 1 & Selected posterior or anterior teeth \\
\hline & 0 & Single tooth type \\
\hline \multirow{4}{*}{$\begin{array}{l}\text { Number of sites } \\
\text { assessed }\end{array}$} & 3 & 150 or more \\
\hline & 2 & $75-149$ \\
\hline & 1 & $40-74$ \\
\hline & 0 & $<40$ \\
\hline \multirow[t]{2}{*}{ Study setting } & 2 & In vivo \\
\hline & 0 & In vitro \\
\hline \multirow[t]{3}{*}{ Number of observers } & 2 & 4 or more \\
\hline & 1 & $2-3$ \\
\hline & 0 & 1 \\
\hline \multirow[t]{3}{*}{ Test reliability report } & 2 & $\begin{array}{l}\text { Inter- and intraevaluator reliability } \\
\text { reported }\end{array}$ \\
\hline & 1 & $\begin{array}{l}\text { Either intra- or intraevaluator } \\
\text { reliability reported }\end{array}$ \\
\hline & 0 & No evaluator reliability reported \\
\hline \multirow[t]{3}{*}{ Validation method } & 2 & $\begin{array}{l}\text { Light microscopy (stereo/mono) } \\
\text { with/without dye of sectioned } \\
\text { tooth }\end{array}$ \\
\hline & 1 & $\begin{array}{l}\text { Other visual or radiographic } \\
\text { assessment of sectioned tooth }\end{array}$ \\
\hline & 0 & Assessment of unsectioned tooth \\
\hline \multirow[t]{2}{*}{ Validation criteria } & 1 & Criteria explicitly stated \\
\hline & 0 & Criteria not explicitly stated \\
\hline \multirow[t]{2}{*}{ Validation reliability } & 1 & $\begin{array}{l}\text { Intra- and interevaluator reliability } \\
\text { reported }\end{array}$ \\
\hline & 0 & No reliability reported \\
\hline
\end{tabular}

was if the permanent dentition was a parameter individually as well as in combination with primary dentition. Studies evaluating the cleaning efficiency were only included.

\section{Study Characteristics}

Main characteristics of the database for the in vitro studies are discussed in Table 3. The most common method for the evaluation of cleaning efficiency was checking the removal of ink from the middle third, cervical third and apical third of canals. Other methods used to evaluate the cleaning efficiency are the smear layer

Flowchart 1: Inclusion of studies

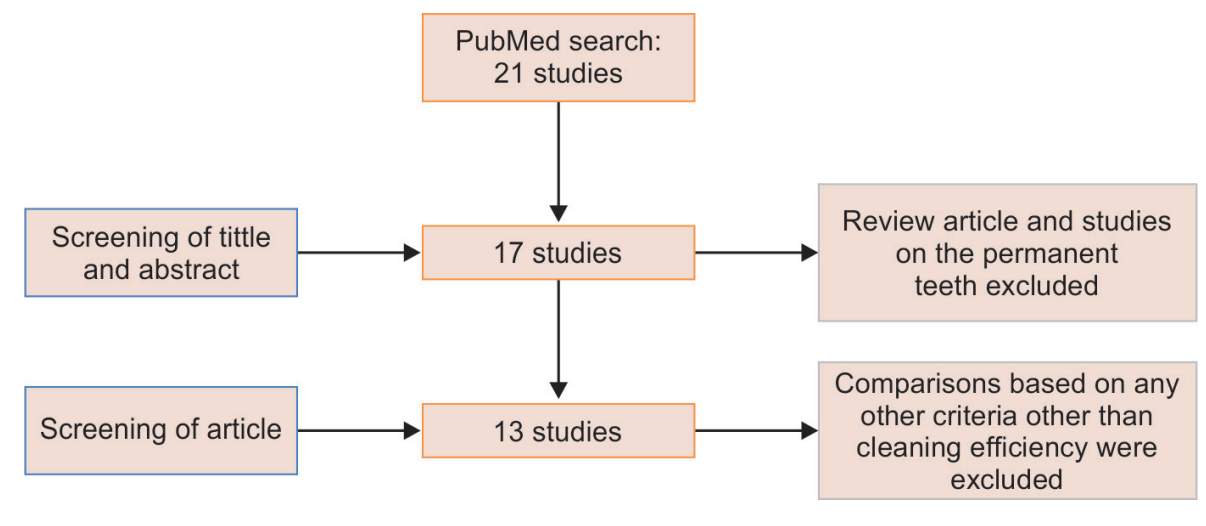


Table 3: Overview of the included studies

\begin{tabular}{|c|c|c|c|c|c|}
\hline S. no. & $\begin{array}{l}\text { Name of author, year } \\
\text { of publication }\end{array}$ & Sample size & $\begin{array}{l}\text { Number of samples according to } \\
\text { the instrumentation technique } \\
\text { used }\end{array}$ & $\begin{array}{l}\text { Methodology used for } \\
\text { comparison }\end{array}$ & $\begin{array}{l}\text { Comparative analysis } \\
\text { data }\end{array}$ \\
\hline 1 & Silva et al., 2004 & $\begin{array}{l}33 \text { mesial and } \\
\text { distal roots }\end{array}$ & $\begin{array}{l}\text { K-file-13 } \\
\text { Profile } 04-13 \\
\text { Control-7 }\end{array}$ & $\begin{array}{l}\text { Removal of injected India } \\
\text { Ink from the cervical, middle } \\
\text { and apical third with } \\
\text { stereoscopic magnifying } \\
\text { glass }\end{array}$ & $\begin{array}{l}\text { Group I: score } 1 \\
\text { Group II: score } 1 \\
\text { Control group: score } 3\end{array}$ \\
\hline 2 & Kummer et al., 2007 & 80 primary teeth & $\begin{array}{l}\text { K-file-40 } \\
\text { Hero } 642 \text { files-40 }\end{array}$ & $\begin{array}{l}\text { Pre- and post-images taken } \\
\text { with Olympus DP } 12 \text { DIGITAL } \\
\text { Camera attached to } \\
\text { stereomicroscope revealing } \\
\text { the amount dentin removal }\end{array}$ & $\begin{array}{l}\text { Manual } \\
\text { Ct: } 0.19 \pm 0.12 \\
\text { Mt: } 0.19 \pm 0.07 \\
\text { At: } 0.22 \pm 0.18 \\
\text { Rotary } \\
\text { Ct: } 0.34 \pm 0.29 \\
\text { Mt: } 0.13 \pm 0.14 \\
\text { At: } 0.14 \pm 0.09\end{array}$ \\
\hline 3 & $\begin{array}{l}\text { Moghaddam et al., } \\
2009\end{array}$ & $\begin{array}{l}23 \text { primary molars } \\
\text { ( } 68 \text { canals) }\end{array}$ & $\begin{array}{l}\text { K-files-30 } \\
\text { Rotary flex files-30 } \\
\text { Control-8 }\end{array}$ & $\begin{array}{l}\text { Removal of injected India } \\
\text { Ink from the cervical, middle } \\
\text { and apical third with } \\
\text { stereoscopic microscope }\end{array}$ & $\begin{array}{l}\text { Manual } \\
\text { Ct: score } 0 \\
\text { Mt: score } 1 \\
\text { At: score } 1 \\
\text { Rotary } \\
\text { Ct: score } 1 \\
\text { Mt: score } 1 \\
\text { At: score } 1 \\
\text { Control group } \\
\text { Score } 3\end{array}$ \\
\hline 4 & Madan et al., 2011 & $\begin{array}{l}75 \text { primary molars } \\
\text { root canals }\end{array}$ & $\begin{array}{l}\text { K-files-30 } \\
\text { Profiles-30 } \\
\text { Control-15 }\end{array}$ & $\begin{array}{l}\text { Removal of India ink from } \\
\text { cervical, middle and apical } \\
\text { third with magnifying glass }\end{array}$ & $\begin{array}{l}\text { Ct: group II > group I } \\
\text { Mt: group II = group I } \\
\text { At: group I > group II }\end{array}$ \\
\hline 5 & Pinheiro et al., 2012 & 15 primary molars & $\begin{array}{l}\text { K-file- } 5 \\
\text { Hybrid instrumentation } \\
\text { with ProTaper and K files-5 } \\
\text { ProTaper-5 }\end{array}$ & $\begin{array}{l}\text { Residual debris and smear } \\
\text { layer removal was assessed } \\
\text { and scored by SEM analysis. } \\
\text { CFU and percentage of } \\
\text { reduction of E. Fecalis was } \\
\text { also measured. }\end{array}$ & $\begin{array}{l}\text { Score for debris } \\
\text { Mt: score } 1(83.33) \\
\text { Ht: score } 2(83.33) \\
\text { Rt: score } 2(100) \\
\text { Score for smear layer } \\
\text { Mt: score } 3(83.33) \\
\text { Ht: score } 2(100) \\
\text { Rt: score } 2(66.66) \\
\text { CFU } \\
\text { MT: } 96.90 \pm 1.30 \\
\text { HT: } 99.58 \pm 0.62 \\
\text { RT: } 98.68 \pm 1.08\end{array}$ \\
\hline 6 & Azar et al., 2012 & $\begin{array}{l}60 \text { primary molars } \\
\text { ( } 160 \text { primary molar } \\
\text { root canal) }\end{array}$ & $\begin{array}{l}\text { K-files-20 } \\
\text { Protaper-20 } \\
\text { Mtwo rotary-20 }\end{array}$ & $\begin{array}{l}\text { Removal of injected India } \\
\text { Ink from the cervical, middle } \\
\text { and apical third with } \\
\text { stereoscopic magnifying } \\
\text { glass }\end{array}$ & $\begin{array}{l}\text { K-file } \\
\text { Apical third: score } 1 \\
\text { Middle third: score } 1 \\
\text { Coronal third: score } 0 \\
\text { Protaper } \\
\text { Apical third: score } 0 \\
\text { Middle third: score } 0 \\
\text { Coronal third: score } 0 \\
\text { Mtwo } \\
\text { Apical third: score } 0 \\
\text { Middle third: score } 0 \\
\text { Coronal third: score } 0\end{array}$ \\
\hline
\end{tabular}


Contd...

\begin{tabular}{|c|c|c|c|c|c|}
\hline S. no. & $\begin{array}{l}\text { Name of author, year } \\
\text { of publication }\end{array}$ & Sample size & $\begin{array}{l}\text { Number of samples according to } \\
\text { the instrumentation technique } \\
\text { used }\end{array}$ & $\begin{array}{l}\text { Methodology used for } \\
\text { comparison }\end{array}$ & $\begin{array}{l}\text { Comparative analysis } \\
\text { data }\end{array}$ \\
\hline 7 & Musale et al., 2014 & 60 primary molars & $\begin{array}{l}\text { K flies-15 } \\
\text { ProFiles 0.04-15 } \\
\text { ProTaper-15 } \\
\text { Hero Shaper 0.04-15 }\end{array}$ & $\begin{array}{l}\text { CBCT and removal of } \\
\text { injected India Ink from the } \\
\text { cervical, middle and apical } \\
\text { third with stereoscopic } \\
\text { magnifying glass }\end{array}$ & $\begin{array}{l}\text { K file: } 0.93 \pm 0.66 \\
\text { ProFiles: } 0.68 \pm 0.50 \\
\text { ProTaper: } 0.48 \pm 0.38 \\
\text { Hero shaper: } 0.58 \pm 0.49\end{array}$ \\
\hline 8 & Katge et al., 2014 & $\begin{array}{l}84 \text { primary molars } \\
\text { (120 root canals) }\end{array}$ & $\begin{array}{l}\text { K files-30 } \\
\text { ProTaper-30 } \\
\text { Wave One-30 } \\
\text { Control-30 }\end{array}$ & $\begin{array}{l}\text { Ink removal with stereo- } \\
\text { microscopic evaluation }\end{array}$ & $\begin{array}{l}\text { K file: } 3.60 \pm 1.99 \\
\text { Protaper: } 3.13 \pm 1.76 \\
\text { Wave One: } 2.53 \pm 1.46\end{array}$ \\
\hline 9 & $\begin{array}{l}\text { Fatemeh Ramezanali } \\
\text { et al., } 2015\end{array}$ & 100 primary molars & $\begin{array}{l}\text { K files-20 } \\
\text { K flies + Mtwo rotary } \\
\text { instruments-20 } \\
\text { Saline-20 } \\
\text { Positive control-20 } \\
\text { Negative control-20 }\end{array}$ & $\begin{array}{l}\text { Removal of injected India } \\
\text { Ink from the cervical, middle } \\
\text { and apical third with stereo- } \\
\text { scopic magnifying glass }\end{array}$ & $\begin{array}{l}\text { CT: Mtwo }(1.35 \pm 1.04) \\
\text { MT: Mtwo }(1.15 \pm 0.93) \\
\text { AT: Mtwo }(0.80 \pm 0.69)\end{array}$ \\
\hline 10 & Poornima et al., 2016 & 20 primary teeth & $\begin{array}{l}\text { K files-10 } \\
\text { Mtwo-10 }\end{array}$ & $\begin{array}{l}\text { Spiral computed analysis } \\
\text { before and after instru- } \\
\text { mentation }\end{array}$ & $\begin{array}{l}\text { Pre instrumentation } \\
\text { K files: } 0.0172 \pm 0.006 \\
\text { Mtwo: } 0.0180 \pm 0.003 \\
\text { Post instrumentation } \\
\text { K files: } 0.0247 \pm 0.007 \\
\text { Mtwo: } 0.0355 \pm 0.008\end{array}$ \\
\hline 11 & $\begin{array}{l}\text { Selvakumar et al., } \\
2016\end{array}$ & 75 primary teeth & $\begin{array}{l}\mathrm{K} \text { files- } 25 \\
\mathrm{~K}_{3} \text { rotary. } 02-25 \\
\mathrm{~K}_{3} \text { rotary. } 04-25\end{array}$ & $\begin{array}{l}\text { Light speed plus CT scanner } \\
\text { before and after instru- } \\
\text { mentation }\end{array}$ & $\begin{array}{l}\text { K file: } 0.13 \pm 0.20 \text { at AT } \\
\mathrm{K}_{3} \text { 0.02: } 0.10 \pm 0.12 \text { at AT } \\
\mathrm{K}_{3} \text { 0.04: } 0.31 \pm 0.07 \text { at AT }\end{array}$ \\
\hline 12 & Ramazani et al., 2016 & $\begin{array}{l}64 \text { primary } \\
\text { mandibular } \\
\text { second molars }\end{array}$ & $\begin{array}{l}\text { K files-16 } \\
\text { Mtwo-16 } \\
\text { Single Reciproc 0.08-16 } \\
\text { Control-16 }\end{array}$ & $\begin{array}{l}\text { CBCT and removal of } \\
\text { injected India Ink from the } \\
\text { cervical, middle and apical } \\
\text { third with stereoscopic } \\
\text { magnifying glass }\end{array}$ & $\begin{array}{l}\text { Score } 1 \text { at AT } \\
\text { K files: } 37.5 \% \\
\text { Mtwo: } 50 \% \\
\text { Reciproc: } 62.5 \% \\
\text { Shaping } \\
\text { K files: } 31.2 \% \\
\text { Mtwo: } 81.2 \% \\
\text { Reciproc: } 75 \%\end{array}$ \\
\hline 13 & $\begin{array}{l}\text { Subramaniam et al., } \\
2016\end{array}$ & $\begin{array}{l}30 \text { primary } \\
\text { maxillary incisors }\end{array}$ & $\begin{array}{l}\text { Group I: heroshapers } \\
\text { Group II: manual instru- } \\
\text { mentation with NiTI K files } \\
\text { Group III: manual instru- } \\
\text { mentation with stainless steel } \\
\text { K-files }\end{array}$ & $\begin{array}{l}\text { Smear layer removal was } \\
\text { examined in the coronal, } \\
\text { middle and apical third using } \\
\text { SEM under } 1,000 \times \text { magni- } \\
\text { fication }\end{array}$ & $\begin{array}{l}\text { Apical third } \\
\text { Group I: } 3.60 \pm 1.17 \\
\text { Group II: } 2.60 \pm 0.70 \\
\text { Group III: } 3.30 \pm 1.25 \\
\text { Middle third: } \\
\text { Group I: } 1.70 \pm 0.67 \\
\text { Group II: } 2.20 \pm 1.03 \\
\text { Group III: } 2.00 \pm 0.82 \\
\text { Coronal third } \\
\text { Group I: } 1.20 \pm 0.42 \\
\text { Group II: } 1.70 \pm 0.82\end{array}$ \\
\hline
\end{tabular}

removal, pre and post images taken with stereomicroscope, cone beam computed tomography (CBCT) and spiral computed tomography.

Comparison was made between hand files and different system of rotary instruments. The various rotary instrumentation technique included are Mtwo, K3 ProTaper system, Hero Shapers, single RECIPROC, profiles and rotary flex files.
Outcome of the study was based on the evaluation of the method applied in the cervical middle and apical third for most of the studies.

\section{Risk of Bias of the Studies}

The details of the risk of bias assessment rating for the studies are given in Table 4. Out of the 13 studies included, 2 studies showed 


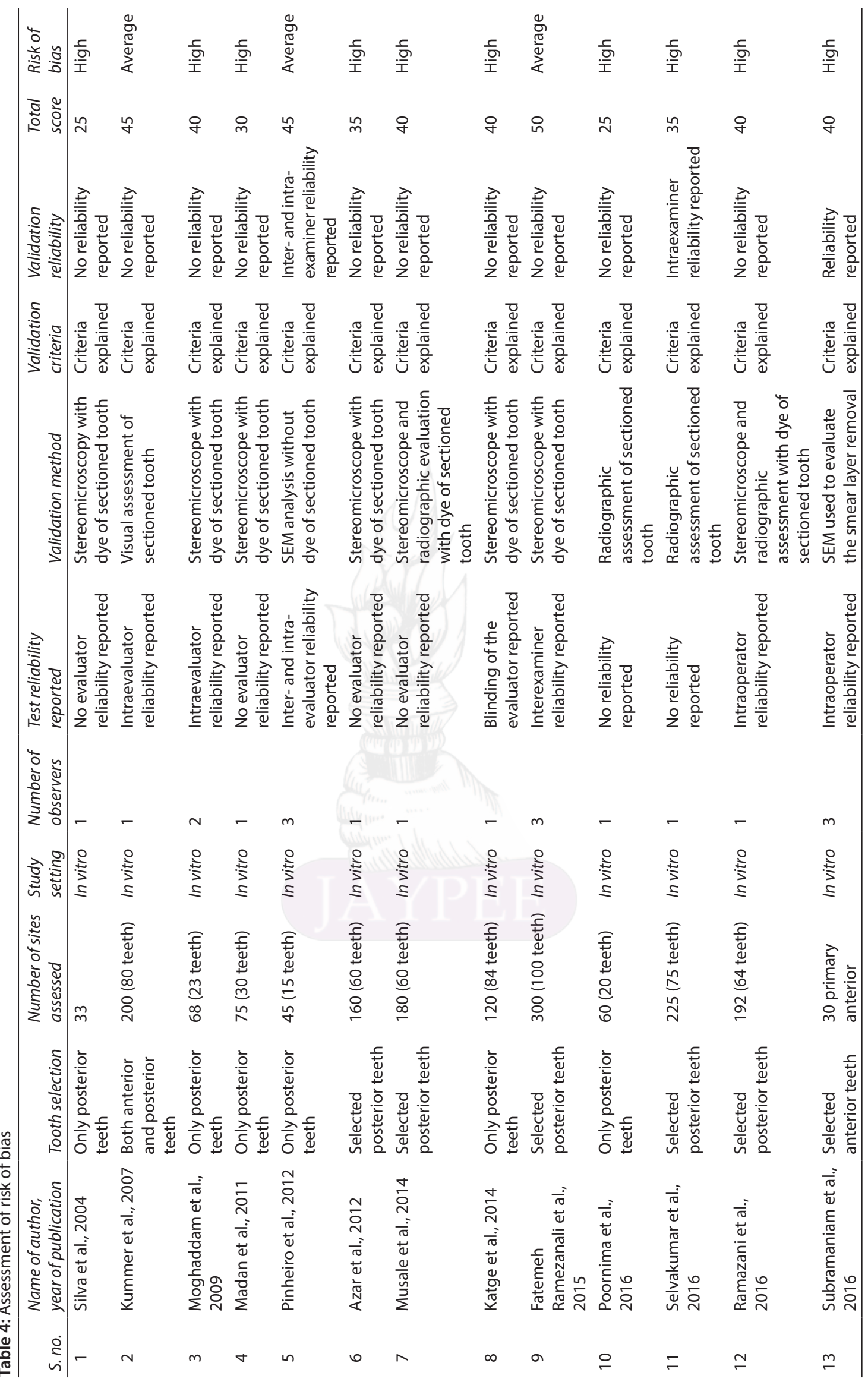


average risk of bias, whereas other 11 showed a high risk of bias. This high risk was basically due to the presence of one observer in the study and absence of inter observer reliability in the studies having two or more observer. Higher risk of bias was due to less sample size included in the study.

\section{Discussion}

Several factors contribute to the clinical success of pulpectomy, such as biomechanical cleaning, ${ }^{10}$ type of restoration, ${ }^{11}$ number of visits ${ }^{10,11}$ and root canal filling material. ${ }^{12}$ Chemomechanical preparation of the root canal includes both mechanical instrumentation and canal irrigation, and it is principally directed toward the elimination of microorganisms from root canal system. ${ }^{13}$ Canal preparation is one of the most important phases of primary root canal treatment and is mainly aimed in the debridement of canal. ${ }^{14,15}$

In vitro studies are carried out to evaluate the efficacy of the root canal instrumentation in primary teeth with rotary and hand instrumentation. The most common method employed for the evaluation of the same was stereomicroscopic evaluation of the sectioned canals checking the removal of ink after the preparation. ${ }^{5,16-22}$ According to Silva et al. there was no significant difference between the cleaning efficiency of profiles 0.04 and manual instrumentation, however it showed significantly better results as compared with no instrumentation. ${ }^{16}$ This finding correlated with Moghaddam et al. ${ }^{17}$ that there was no significant difference in the cleaning efficiency of rotary and hand instruments. The rotary system used here is rotary flex files. The author however advocated that the canals were better cleaned in the cervical third with $\mathrm{K}$ files than rotary flex files. ${ }^{16}$ This result did not agree with Silva et al. ${ }^{16}$ According to Madan et al. ${ }^{5}$ cleaning efficiency was found similar in middle third for both $\mathrm{K}$ files and profiles. They advocated the use of step back technique in the preparation of primary teeth as it cuts less dentin as compared to crown down technique, which correlated with Silva et al. ${ }^{16}$ According to Ramezanali et al., ${ }^{19}$ Mtwo system and $\mathrm{K}$ files showed same cleaning efficiency. This finding was contraindicated by the study by Ramazani et al. ${ }^{20}$ showing better efficiency of Mtwo in the cervical third as compared to $\mathrm{K}$ files. Reciprocating system and Mtwo system, however showed same cleaning efficiency in all the thirds. In accordance with this study, Katge et al. ${ }^{21}$ showed no significant difference in the apical third using Wave One and ProTaper, however Wave One showed better cleaning efficiency in middle thirds. According to Azar et al., ${ }^{22}$ there was no significant difference in the cleaning efficiency between hand and rotary, however ProTaper showed better cleaning efficiency than Mtwo and hand instrumentation. A study by Mudale et al. promoted a modified sequence of instrumentation in primary teeth due to the anatomic variation leading to lateral perforation and unavailability of files designed for primary teeth. ${ }^{20}$ Early coronal enlargement with intro files like ProFile OS, ProTaper SX, and Hero Shaper Endo flare is done to facilitate straight line access by removing the shelf of dentin overlying the canal orifice. ${ }^{18}$ This study advocated better cleaning efficiency of rotary files than manual which is contradicting to studies by other authors. ${ }^{5,16,18,21}$

Radiographic evaluation is another method used in which the dentin removal is checked by the difference in the pre- and postCBCT evaluation. ${ }^{718,23,24}$ Musale et al. ${ }^{18}$ showed better cleaning efficacy with ProTaper and hero shapers show higher mechanical preparation than hand $\mathrm{K}$ files. These findings were correlated with the study by Poornima et al. ${ }^{23}$ which measured the volumetric change in the root canal. In this study, Mtwo system showed higher mechanical preparation with increased volume as compared to hand $\mathrm{K}$ files. This study varied with Selvakumar et al., ${ }^{7}$ which advocated $\mathrm{K}_{3} .06$ system removing less dentin in the coronal third and more dentin in middle and cervical third as compared to hand $\mathrm{K}$ files. Kummer et al. ${ }^{24}$ proved, manual instrumentation removed more dentin as compared to rotary instrumentation in primary teeth. This study evaluated dentin removal by stereomicroscopic measurements obtained from the images of root canal pre and post the instrumentation. Other deciduous molar studies comparing manual files and rotary instrumentation found no significant difference in the amount of dentin removal. ${ }^{16,24}$

Apart from mechanical preparation elimination of microbes also play an important role in assessing the cleaning efficiency. ${ }^{19}$ Pinheiro et al. reveal no significant cleaning efficiency between manual and rotary instrumentation. ${ }^{25}$ This study used a hybrid system of root canal instrumentation which combined the use of stainless steel and NiTi files, showing a greater amount of reduction in the E. fecalis levels. However, no significant difference was found in the removal of debris and smear layer, which is inconsistent with other studies. ${ }^{26,27}$

The latest method employed for the evaluation of the cleaning efficiency of root canal instrumentation is micro-CT. However, no studies have been done using the same. ${ }^{28}$

\section{ConClusion}

Further studies need to be done using high sample size to evaluate the comparative efficiency of rotary and manual instrumentation. A definitive conclusion cannot be drawn from the available literature however, the choice of treatment protocol can be made based on the clinical requirements.

\section{References}

1. Buehler WH, Gilfrich JV, et al. Effect of low temperature phase changes on the mechanical properties of alloys near composition TiNi. J Appl Phys 1963;34(1):1475-1477.

2. Serene TP, Adams JD, et al. Nickel-Titanium Instruments: Applications in Endodontics. St. Louis Missouri, USA: Ishiyaku Euroamerica. Inc.; 1995. pp. 110-112.

3. Grossman L. Endodontics 1776-1976: A bicemental history against the background of general dentistry. J Am Dent Assoc 1976;93:78-87. DOI: 10.14219/jada.archive.1976.0606.

4. Barr ES, Kleier DJ, et al. Use of nickel-titanium rotary files for root canal preparation in primary teeth. Pediatr Dent 2000;22(1):77-78.

5. Madan N, Rathnam A, et al. K-file vs ProFiles in cleaning capacity and instrumentation time in primary molar root canals: an in vitro study. J Ind Soc Pedod Prev Dent 2011;29(1):2-6. DOI: 10.4103/0970-4388. 79907.

6. Crespo S, Cortes $\mathrm{O}$, et al. Comparison between rotary and manual instrumentation in primary teeth. Int J Clin Pediatr Dent 2008;32(4):295-298. DOI: 10.17796/jcpd.32.4.I57I36355u606576.

7. Selvakumar H, Kavitha S, et al. Computed tomographic evaluation of $\mathrm{K} 3$ rotary and stainless steel $\mathrm{K}$ file instrumentation in primary teeth. J Clin Diagn Res 2016;10(1):ZC05-ZC08.

8. Nuvvula S, Bhumireddy JR, et al. Diagnostic accuracy of direct digital radiography and conventional radiography for proximal caries detection in primary teeth: a systematic review. J Ind Soc Pedod Prev Dent 2016;34(4):300-305. DOI: 10.4103/0970-4388. 191406.

9. Bader JD, Shugars DA, et al. A systematic review of the performance of methods for identifying carious lesions. J Public Health Dent 2002;62(4):201-213. DOI: 10.1111/j.1752-7325.2002.tb03446.x.

10. Ingle Jl, Himal V, et al. Endodontics, 5th ed., Hamilton London: BC Decker; 2002. pp. 889-891. 
11. Moskovitz M, Sammara E, et al. Success rate of root canal in primary molars. J Dent 2005;33(1):41-47. DOI: 10.1016/j.jdent.2004.07.009.

12. Mc Donald RE, Avery DR. Dentistry for the child and adolescent, 7th ed., St. Louis: Mosby; 2000. pp. 401-405.

13. Mortazavi M, Mesbahi M. Comparison of zinc oxide and eugenol and vitapex for root canal treatment of necrotic primary teeth. Int J Paediatr Dent 2004;14(6):417-424. DOI: 10.1111/j.1365263X.2004.00544.x.

14. Young GR, Parashos $P$, et al. The principles of techniques for cleaning root canals. Aust Dent J 2007;52(s1):S52-S63. DOI: 10.1111/j.18347819.2007.tb00526.x

15. Cohen S, Hargreaves K. Pathways of pulp, 9th ed., St. Louis: Mosby; 2006. p. 842.

16. Silva LA, Leonardo MR, et al. Comparison of rotary and manual instrumentation techniques on cleaning capacity and instrumentation time in deciduous teeth. J Dent Children 2004;71(1):45-47.

17. Moghaddam KN, Mehran M, et al. Root canal cleaning efficacy of rotary and hand files instrumentation in primary molars. Iran Endod J 2009;4(2):53.

18. Musale PK, Mujawar SA. Evaluation of the efficacy of rotary vs hand files in root canal preparation of primary teeth in vitro using CBCT. Eur Arch Paediatr Dent 2014;15(2):113-120. DOI: 10.1007/s40368-0130072-1.

19. Ramezenali F, Afkhami F, et al. Comparison of cleaning efficacy and instrumentation time in primary molars: Mtwo rotary instruments vs hand K files. Iran Endod J 2015;10(4):240-243.

20. Ramazani N, Mohammadi A, et al. In vitro investigation of the cleaning efficacy, shaping ability, preparation time and file deformation of continuous rotary, reciprocating rotary and manual instrumentations in primary molars. J Dent Res Dent Clin Dent Prospects 2016;10(1): 49-52. DOI: 10.15171/joddd.2016.008.
21. Katge $F$, Patil $D$, et al. Comparison of instrumentation time and cleaning efficiency of manual, rotary systems and reciprocating systems in primary teeth as in vitro studies. J Ind Soc Pedod Prev Dent 2014;32(4):311-316. DOI: 10.4103/0970-4388.140957.

22. Reza Azar M, Safi L, et al. Comparison of the cleaning capacity of Mtwo and ProTaper rotary system and manual instruments in primary teeth. Dent Res J 2012;9(2):146-151. DOI: 10.4103/1735-3327.95227.

23. Poornima $P$, Disha $P$, et al. Volumetric analysis of hand and rotary root canal instrumentation and filling in primary teeth using spiral computed tomography - an in vitro study. Int J Paediatr Dent 2016;26(3):193-198. DOI: 10.1111/ipd.12180.

24. Kummer TR, Calvo MC, et al. Ex vivo study of manual and rotary instrumentation techniques in human primary teeth. Oral Surg Oral Med Oral Pathol Oral Radiol Endod 2008;105(4):e84-e92. DOI: 10.1016/j.tripleo.2007.12.008.

25. Pinheiro SL, Araujo G, et al. Evaluation of cleaning capacity and instrumentation time $\mathrm{f}$ manual, hybrid and rotary instrumentation techniques in primary molars. Int Endod J 2012;45(4):279-385. DOI: 10.1111/j.1365-2591.2011.01987.x.

26. Canglu H, Tekcicek MU, et al. Comparison of conventional, rotary and ultrasonic preparation, different files irrigation regime and 2 sealers in primary molar root canal therapy. Pediatr Dent 2006;28(6):518-523.

27. Subramaniam P, Girish Babu, KL, et al. Effectiveness of Rotary Endodontic Intruments on Smear Layer Removal in Root Canal of Primary Teeth: A Scanning Electron Microscopy Study. J Clin Pediatr Dent 2016;40(2):141-146. DOI: 10.17796/1053-4628-40.2.141.

28. Schäfer $E$, Vlassis $M$. Comparative investigation of two rotary nickel-titanium instruments: ProTaper versus RaCe. Part 2. Cleaning effectiveness and shaping ability in severely curved root canals of extracted teeth. Int Endod J 2004;37(4):239-248. DOI: 10.1111/j.01432885.2004.00783.x. 